\title{
SACCHARIFICATION OF MAIZE AGROWASTES BY CELLULOLYTIC FUNGI ISOLATED FROM EJURA FARMS IN EJURA, GHANA.
}

\author{
H. D. Zakpaa E. E. Mak-Mensah, and F. S. Johnson \\ Department of Biochemistry and Biotechnology, \\ School of Biosciences, KNUST, Kumasi.
}

\begin{abstract}
Maize is the most abundant cereal grown in Ghana and is accompanied by enormous amount of maize agrowastes. This waste which is currently underutilized can be used to produce bioethanol. Saccharification of lignocellulosic materials into simple sugars is a crucial and costly step towards bio-ethanol production from them. This work isolated cellulolytic fungi from soil sampled from Ejura farms which can efficiently hydrolyse maize agrowastes. Ten of the isolates exhibited cellulase activities when screened on Mandel's agar media. Aspergillus niger had the highest significant filter paper activity, carboxymethyl cellulose activity and protein concentration of $0.37 \mathrm{FPU} / \mathrm{ml} 0.7025 \mathrm{U} / \mathrm{ml}$ and $5.62 \mathrm{mg} / \mathrm{ml}$ respectively when the cellulolytic isolates were assayed on corncob based broth media.
\end{abstract}

Keywords: cellulolytic fungi, enzyme activity, lignocellulose

\section{INTRODUCTION}

Maize (Zea mays) is the most abundant cereal produced in Ghana (Asante, 2004). According to Asante (2004), production between 1995 and 2004 had hovered around one million metric tons per annum. This was accompanied by large quantities of maize agro wastes (husk, cobs and stove).

These agrowastes are underutilized. Currently the corncobs are burnt as fuel in the households of peasant rural farmers. The husks are used for wrapping kenkey and the stoves are usually burnt or left in the field. In large commercial farms where harvesting is mechanized, the agrowastes are left on the field and ploughed into the soil.
Production of bio-ethanol from maize agrowastes with cellulase is feasible but is relatively expensive and enzyme cost contributes about 40\% (Howard et al., 2003; Miyamoto, 1997). Search for high cellulase-producing organisms is one way of reducing the higher production cost (Bon and Ferarra, 2007). The objective of this work is to isolate fungi from soil samples from Ejura farms which will efficiently hydrolyze maize agrowastes into simple sugars for bio-ethanol production. Soil was sampled from Ejura farms because the agrowastes are left on the field and ploughed back into the soil making it a good habitat for cellulolytic fungi but has not been explored (Agana, 2007). 


\section{MATERIALS AND METHODS}

\section{Isolation of fungi}

Fungi were isolated from soil samples collected from Ejura farms in Ashanti region. Potato Dextrose Agar (PDA) containing chloramphenicol $(500 \mathrm{mg} / \mathrm{ml})$ to suppress bacterial growth was used as isolation medium. The inoculated plates were incubated at $25^{\circ} \mathrm{C}$ for $4-5$ days. The cultures were further purified by subculturing on PDA. The methods of Burnett and Hunter (1972), Malloch, (1997), Guarro et al., (1999), www.doctorfungus.org, 2008; www. mycologyonline.adelaide.edu.au, 2008 were employed for identification of the isolates.

\section{Screening of fungal isolates for cellulase ac- tivity}

Preliminary screening of isolates was carried out on Mandel agar medium (MAM). MAM was prepared as described by Jeffries (1987) and consisted of the following per liter: $\left(\mathrm{NH}_{4}\right)$ ${ }_{2} \mathrm{SO}_{4} 1.4 \mathrm{~g}, \mathrm{KH}_{2} \mathrm{PO}_{4} 2.04 \mathrm{~g}, \mathrm{CaCl}_{2} 0.3 \mathrm{~g}$, $\mathrm{MgSO}_{4} .7 \mathrm{H}_{2} \mathrm{O} 0.3 \mathrm{~g}$, Urea 2.1g, Citric acid 0.25 g, Tween $802 \mathrm{ml}$, Avicel cellulose $10 \mathrm{~g}$, Peptone1 $\mathrm{g}$, and Trace metal stock solution $1 \mathrm{ml}$. The trace metal stock solution consisted of the following chemicals per $500 \mathrm{ml}: \mathrm{FeSO}_{4} 2.55 \mathrm{~g}$, $\mathrm{MnSO}_{4} \cdot \mathrm{H}_{2} \mathrm{O} 0.93 \mathrm{~g}, \mathrm{ZnSO}_{4} \cdot \mathrm{H}_{2} \mathrm{O} 1.78 \mathrm{~g}$, Co $\left(\mathrm{NO}_{3}\right)_{2} \cdot 6 \mathrm{H}_{2} \mathrm{O} 1.25 \mathrm{~g}$, and Conc. $\mathrm{HCl} 5 \mathrm{ml}$.

Colony diameter and clearing zone diameter of the isolates were measured and clearing zone diameter to colony diameter ratios were calculated. Based on these ratios the nine highest isolates were selected for further screening.

Further screening was performed in corncobsbased broth (CBB) medium. Preparation of CBB was similar to MAM except that cellulose was substituted with corncob powder. Corncobs were sun dried and pounded. It was then oven dried at $120^{\circ} \mathrm{C}$ for 3 days after which it was milled and sieved (Mesh series 70, Endecott filter) to obtain the powder. Hundred milliliters of CBB medium was dispensed into each 250 $\mathrm{ml}$ conical flasks. Inoculum of each isolate was prepared by flooding a 4-days old slant of that isolate with $10 \mathrm{ml}$ sterile distilled water. With the aid of flamed inoculating loop, conidia were scratched and the tubes were shaken vigorously to break the clumps of conidia to obtain a homogenous suspension. The spores of each isolate were estimated with hyaemocytometer (Improved Neubauer Haemocytometer). Approximately $1 \times 10^{7}$ spores of each isolate were inoculated into a conical flask containing 100 $\mathrm{ml}$ of autoclaved CBB under laminar flow. The inoculated conical flasks were incubated on a shaker (G24 Environmental incubator shaker) at $150 \mathrm{rpm}$ at room temperature $\left(25^{\circ} \mathrm{C}\right)$ for 6 days. Five milliliters aliquots were taken from each inoculated medium 3 and 6 days after inoculation. The aliquots were centrifuged in centrifuge (Centrikon T-42K) at $10000 \mathrm{~g}$ for 10 min at $4^{\circ} \mathrm{C}$, the supernatants decanted into new tubes and stored frozen for few days for enzyme assay. Freezing and thawing has less effect on enzyme activity for short period (Waravdekar et al., 1964)

\section{Determination of enzyme activity}

Cellulase activities were determined by filter paper assay (FPA) and carboxymethyl cellulose assay (CMCA). The procedures for these assays were adopted from those previously described (Jeffries, 1987; Ghose, 1987 and Adney and Baker, 1996). Whatman No.1 filter paper and carboxymethyl cellulose (degree of substitution $=0.7$ ) were substrates in FPA and CMCA respectively. Reducing sugars released from these assays were quantified by DNS assay. The DNS reagent $(1 \%$ DNS solution and $40 \%$ potassium sodium tartrate or Rochelle salt solution) was prepare as described by Wang (2008). Three milliters of DNS reagent and one $\mathrm{ml}$ potassium sodium tartrate solution were added to the content of each assay tube. The contents of the tubes were boiled in a vigorously boiling water bath for 5 minutes and then added to each tube and transferred to cold icewater bath. One $\mathrm{ml}$ of potassium sodium tartrate was then added to the content of each tube and transferred to ice-cold water bath. Intensity of colour formation was determined by measuring absorbance at $540 \mathrm{~nm}$ with spectrophotometer (Helios UV Visible Spectrometer). Amount of reducing sugars released was deter- 


\section{Zakpaa et al.}

mined from glucose standard curve (glucose $(\mathrm{mg} / 0.5 \mathrm{ml})$ against absorbance at $540 \mathrm{~nm})$. FP and CMC activities were estimated: Filter paper unit, $\mathrm{FPU}=\mathrm{mg}$ glucose released $\times 0.185$ and $\mathrm{CMC}$ Unit $=\mathrm{mg}$ of glucose released $\times 0.37$.

Total proteins of the isolate supernatants were determined by Biuret method. Four milliliters of Biuret reagent was added to $1 \mathrm{ml}$ of the supernatant and incubated at $37^{\circ} \mathrm{C}$ for 20 minutes. The colour intensity was determined at an absorbance of $540 \mathrm{~nm}$ and the protein concentration calculated from egg albumin curve.

Experimental Design and Statistical Analysis All the tests were laid in complete randomized design and each treatment was tested in tripli-

Table 1: Number of species isolated in each genus

\begin{tabular}{lc}
\hline Genera & Number of species \\
\hline Aspergillus & 4 \\
Trichoderma & 1 \\
Penicillium & 2 \\
Mucor & 1 \\
Fusarium & 1 \\
Rhodotorula & 1 \\
Acremonium & 1 \\
Coccidioides & 1 \\
\hline
\end{tabular}

cate. ANOVA analyses were carried out with Assistat 7.5 beta. Graphs were plotted with Microsoft excel.

\section{RESULTS AND DISCUSSION}

Twelve species from 8 different genera were isolated from the soil. These were Aspergillus terreus, Trichoderma sp. Aspergillus versicolor, Penicillium sp.9, Mucor sp. Aspergillus flavus, Aspergillus niger, Fusarium sp. Penicillium sp. 7, Rhodotorula sp. Acremonium sp. and Coccidioides sp.

The number of species from each genus is illustrated in Table 1. The genus Aspergillus was the most diverse followed by Penicillium species.

Ten out of the 12 isolated species exhibited cellulolytic activity. The number of cellulolytic fungi isolated is comparable to those cited in literature. Kader and Omar (1998), in a scientific expedition to Sayab-Kinabalu park at Sabah in Malaysia isolated 16 cellulolytic fungi species. Baig et al.,(2003), in a similar work isolated 12 cellulolytic fungi from a banana farm at Maharashtra in India. Coccidioides $s p$ was not tested for cellulolytic activity because it is highly infectious as human pathogen (www.mycology.adelaide.edu.au/Mycoses/ Dimorphic_systemic, 2008)

Table 2: Mycelial diameter in centimeters of the isolates on MAM

\begin{tabular}{llc}
\hline \multicolumn{1}{c}{ Isolates } & Mean diameter at 3 days & $\begin{array}{c}\text { Mean diameter for 6 } \\
\text { days }\end{array}$ \\
\hline A. terreus & $3.4^{\mathrm{b}}$ & $4.22^{\mathrm{b}}$ \\
Trichoderma & $7.26^{\mathrm{a}}$ & $8.31^{\mathrm{a}}$ \\
A. versicolor & $1.50^{\mathrm{d}}$ & $2.13^{\mathrm{d}}$ \\
Penicillium sp.9 & $2.50^{\mathrm{c}}$ & $3.00^{\mathrm{c}}$ \\
Mucor sp. & $1.23^{\mathrm{d}}$ & $0.41^{\mathrm{f}}$ \\
A. flavus & $3.5^{\mathrm{b}}$ & $4.36^{\mathrm{b}}$ \\
A. niger & $2.4^{\mathrm{c}}$ & $3.93^{\mathrm{b}}$ \\
Fusarium sp & $1.57^{\mathrm{d}}$ & $2.49^{\mathrm{cd}}$ \\
Penicillium sp.7 & $1.30^{\mathrm{d}}$ & $2.220^{\mathrm{d}}$ \\
Rhodotorula $s p$. & $0.13^{\mathrm{e}}$ & $0.21^{\mathrm{f}}$ \\
Acremonium $s p$. & $1.10^{\mathrm{d}}$ & $1.18^{\mathrm{e}}$ \\
\hline
\end{tabular}

The alphabets represent the order of the means within a column which are significantly different at $P=5 \%$ by Duncan's Multiple Range Test (DMRT). Means in a column with different superscripts are significantly different.

* Measurement was not taken after 3 days.

Journal of Science and Technology @ KNUST April 2010 
The isolates were cultured on Mandel agar media (MAM). Mycelial and clearing zone diameters were measured on the 3,5 and 6 days after inoculation. The average was calculated as mean (Table 2). The 3 days mycelia diameter mean is of importance because Mucor sp. exhibited profuse aerial growth which made measurement after third day impracticable. The mean of mycelial diameter is an indicator of the ability of the isolates to hydrolyze Avicel cellulose (pure crystalline cellulose).

There were significant differences $(p<0.05)$ between the mean mycelial diameters for both the 3 and 6 days period. Trichoderma sp. had the highest mean mycelial diameter for 3 days period and was significantly different from other species, followed by $A$. flavus, $A$. terreus, Penicillium sp.9 and A. niger whilst Rhodotorula sp. recorded the least. For the mean mycelia diameter over the 6 days period, Trichoderma sp. recorded the highest followed by $A$. flavus, A. terreus and A. niger, in that order.

All the 10 cellulolytic species isolated had been reported to exhibit cellulase activity with Trichoderma sp. and Aspergillus sp. being prominent (Lynd et al., 2002; Miyamoto,1997; Bon and Ferrara, 2007; Rajesh et al., 2008). Of the 10 cellulolytic species, 4 were Aspergillus species and 2 were Penicillium species. Aspergillus and Penicillium species were the abundant cellulolytic species isolated from Rawalpindi district in Pakistan by Khalid et al., (2006).

Clearing zone diameter to mycelial diameter ratio indicates the ability of the isolates to exude extracellular enzymes into the media. The ratios for 3 and 6 days periods are shown in Table 3. The ratios for 3 days are preferred to 6 days period because the petri plate size restricted the clearing zone diameter of fast growing Trichoderma species. Profuse aerial growth of Mucor sp. made measurement after 3 days impracticable. Mucor $s p$. had the highest ratio whilst Rhodotorula $s p$. recorded the least ratio of 1 implies that there was no difference between its clearing zone diameter and mycelial diameter.

The ability of a fungus to hydrolyze pure crystalline cellulose does not necessarily translate into ability to hydrolyze lignocellulosics (Lynd et al., 2002). Nine of the cellulolytic isolates were cultured in $\mathrm{CBB}$ at $\mathrm{pH} 5.0$ at $25^{\circ} \mathrm{C}$. The mean enzyme activities and protein concentrations of the isolates were determined. The unit of activity (U) is defined as the amount of enzyme liberating $1 \mu \mathrm{mol}$ glucose per minute in a standard assay.

Table 3: Clearing zone to mycelial diameter ratios for the isolates

\begin{tabular}{lcc}
\hline Isolates & Ratio at 3 days & Ratio at 6 days \\
\hline A. terreus & $1.16^{\mathrm{bc}}$ & $1.28^{\mathrm{ab}}$ \\
Trichoderma & $1.18^{\mathrm{bc}}$ & $1.08^{\mathrm{cd}}$ \\
A. versicolor & $1.09^{\mathrm{bc}}$ & $1.12^{\mathrm{bc}}$ \\
Penicillium sp.9 & $1.11^{\mathrm{bc}}$ & $1.00^{\mathrm{d}}$ \\
Mucor sp. & $1.97^{\mathrm{a}}$ & $1.32^{\mathrm{ab}}$ \\
A. flavus & $1.34^{\mathrm{bc}}$ & $1.33^{\mathrm{ab}}$ \\
A. niger & $1.43^{\mathrm{b}}$ & $1.47^{\mathrm{a}}$ \\
Fusarium sp & $1.39^{\mathrm{b}}$ & $1.2^{\mathrm{ab}}$ \\
Penicillium sp.7 & $1.09^{\mathrm{bc}}$ & $1.14 \mathrm{~b}^{\mathrm{c}}$ \\
Rhodotorula $s p$. & $1.00^{\mathrm{c}}$ & $1.00^{\mathrm{d}}$ \\
Acremonium $s p$. & $1.09^{\mathrm{bc}}$ & $1.10^{\mathrm{cd}}$
\end{tabular}

The alphabets represent the order of the means within a column which are significantly different at $P=5 \%$ by Duncan's Multiple Range Test (DMRT). Means in a column with different superscripts are significantly different.

* Measurement was not taken after 3 days. 


\section{Zakpaa et al.}

Filter paper activity (FPA) measures the overall activity of all the cellulase components (exoglucanase, endoglucanase and $\beta$-glucosidase). There was significant difference $(p<0.05)$ between FPA of the isolates. Fig. 1 illustrates the mean FPA of the isolates. $A$. niger had the highest mean FPA of 0.3648 FP $\mathrm{U} / \mathrm{ml}$ and was significantly different. This is comparable to similar works cited in literature. Immanuel et al., (2007) reported of isolated $A$. niger strain with maximum FPA of $0.262 \mathrm{U} / \mathrm{ml}$ on sawdust-based medium. Baig et al., (2003) also reported of Trichoderma lignorum isolated from banana field with maximum FPA of 0.45 $\mathrm{U} / \mathrm{ml}$ on banana-based medium.
A. niger was followed by Trichoderma $s p$. and A. flavus with $0.3412 \mathrm{U} / \mathrm{ml}$ and $0.3208 \mathrm{U} / \mathrm{ml}$ respectively. Fusarium $s p$. and Penicillium sp.7 recorded the least.

Carboxymethyl Cellulose (CMC) activity measures endoglucanase activity. There was significant difference $(p<0.05)$ between the CMC activity of the isolates and the mean CMC activities are illustrated on Fig. 2. A. niger had the highest mean CMC activity of $0.7025 \mathrm{U} / \mathrm{ml}$ and was significantly different. It was followed by A. flavus and Trichoderma $s p$. with $0.5938 \mathrm{U} / \mathrm{ml}$ and $0.5878 \mathrm{U} / \mathrm{ml}$ respectively. A. terreus, Penicillium sp. 9, Fusarium $s p$. and Penicillium sp. 7 were the least significant.

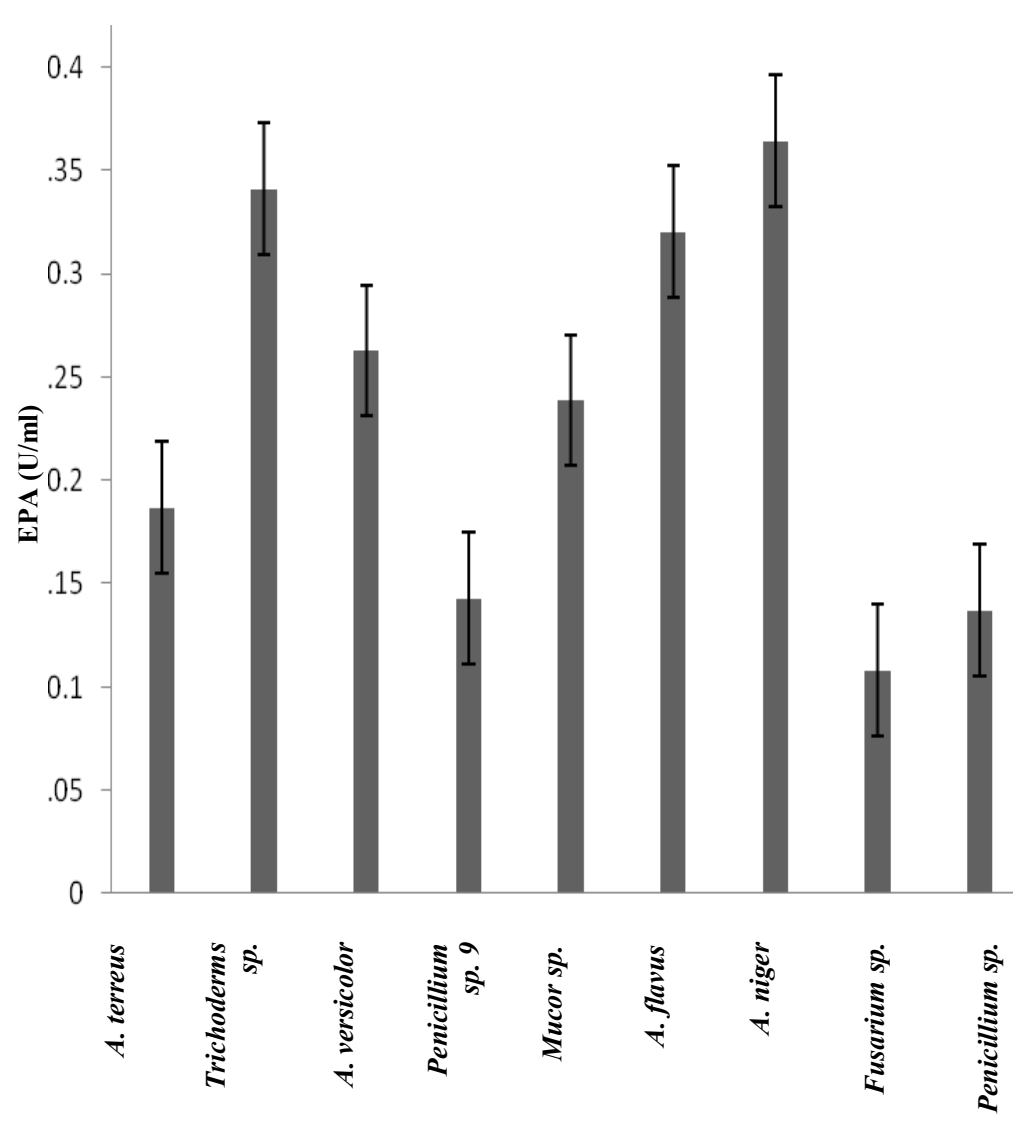

Cellulolytic isolates

Fig. 1: Mean FPA (U/ml) of the cellulolytic isolates in CBB over 6 days period 
Most enzymes are proteins so protein concentration can indicates enzyme concentration. There was significant difference $(\mathrm{p}<0.05)$ in the mean protein concentration of the isolates. The mean protein concentration of the isolates is illustrated in Fig 3. A. niger had the highest protein concentration of $5.6155 \mathrm{mg} / \mathrm{ml} \mathrm{fol-}$ lowed by A. flavus with $4.5493 \mathrm{mg} / \mathrm{ml}$ though the difference between them is not significant. Fusarium sp. was the least significant.

A. niger had the highest enzyme activities (FPA and CMCA) and protein concentration. The higher FPA may be due to superior composition of its cellulase component (Olofsson et al., 2008) or possession of other complementary enzymes such as lignase and hemicellulase (Baig et al., 2004). The effective hydrolysis of lignocellulosics is determined by the constitution of the three components of cellulase.
Aspergillus genus is notable for its higher endoglucanase activity measured as $\mathrm{CMC}$ activity (Miyamoto, 1997). Since there is a direct link between protein concentration and enzyme concentration, it might account for the higher protein concentration of $A$. niger.

Although Trichoderma sp. had the highest significant mean mycelial diameter on Mandel agar medium: an indicator of cellulase activity (Maheshwari et al., 2000), its enzyme activities (FPA and CMCA) on CBB came next to $A$. niger. This may be due to the impediments posed by the lignocellulosic apart from crystallinity. The optimal composition of cellulase determines lignocellulosic hydrolysis (Olofsson et al., 2008). The cellulase constituents in this case were predetermined by the source of the enzyme (isolate).

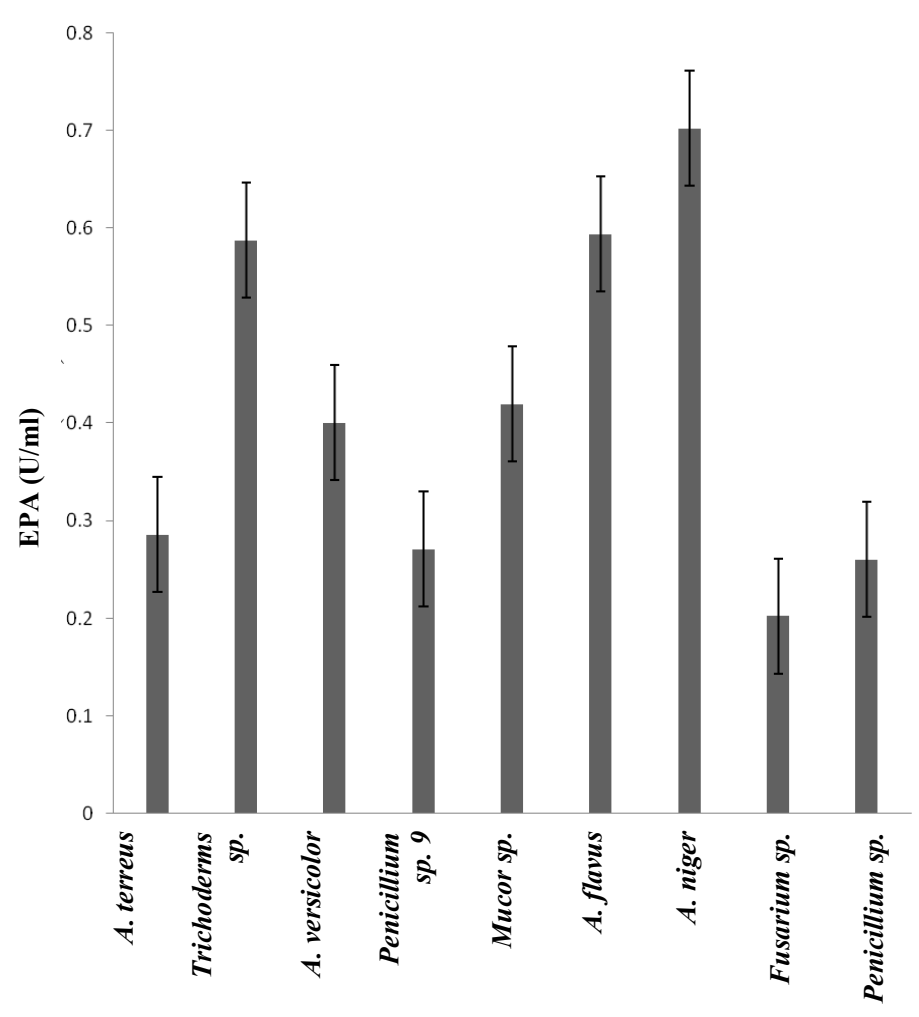

Cellulolytic isolates

Fig. 2: Mean CMC activity (U/ml) of cellulolytic isolates in CBB over 6 days period 


\section{CONCLUSION}

Soil from Ejura farms soil harbours cellulolytic fungi out of which Aspergillus niger was isolated. Aspergillus niger produced cellulase used to efficiently hydrolyze maize agro-waste (corncobs) into reducing sugars. The mean FP activity of $0.3648 \mathrm{U} / \mathrm{ml}$ on corncob based medium is appreciable.

\section{ACKNOWLEDGEMENTS}

We are grateful to the management of Ejura farms, for allowing us to take soil samples from their farms.

\section{REFERENCES}

Adney, B. and Baker, J. (1996). Measurement of Cellulase Activities. NREL/MRI. Laboratory Analytical Procedure LAP-006.
Asante, A. (2004). Assessment of food import and food aid against support for agricultural development, the case of Ghana. Draft report for FAO Regional Office p10.

Baig, M.M., Mane, V.P., More, D.R., Shinde, L.P. and Baig, M.I. (2003). Utilization of banana agricultural waste: production of cellulases by soil fungi. J. Environ Biol. 24 (2):173-6.

Baig, M.V., Baig, M.L.B., Baig, M.I.A. and Yasmeen, M. (2004). Saccharification of banana agro waste by cellulolytic enzymes. Afr. J. Biotechnol. 3:447-450.

Bon, E.P.S. and Ferrara, M.A. (2007). Bioethanol production via enzymatic hydrolysis of cellulosic biomass. http://www.fao.org/ biotech/seminaroct2007.htm, July, 2008.

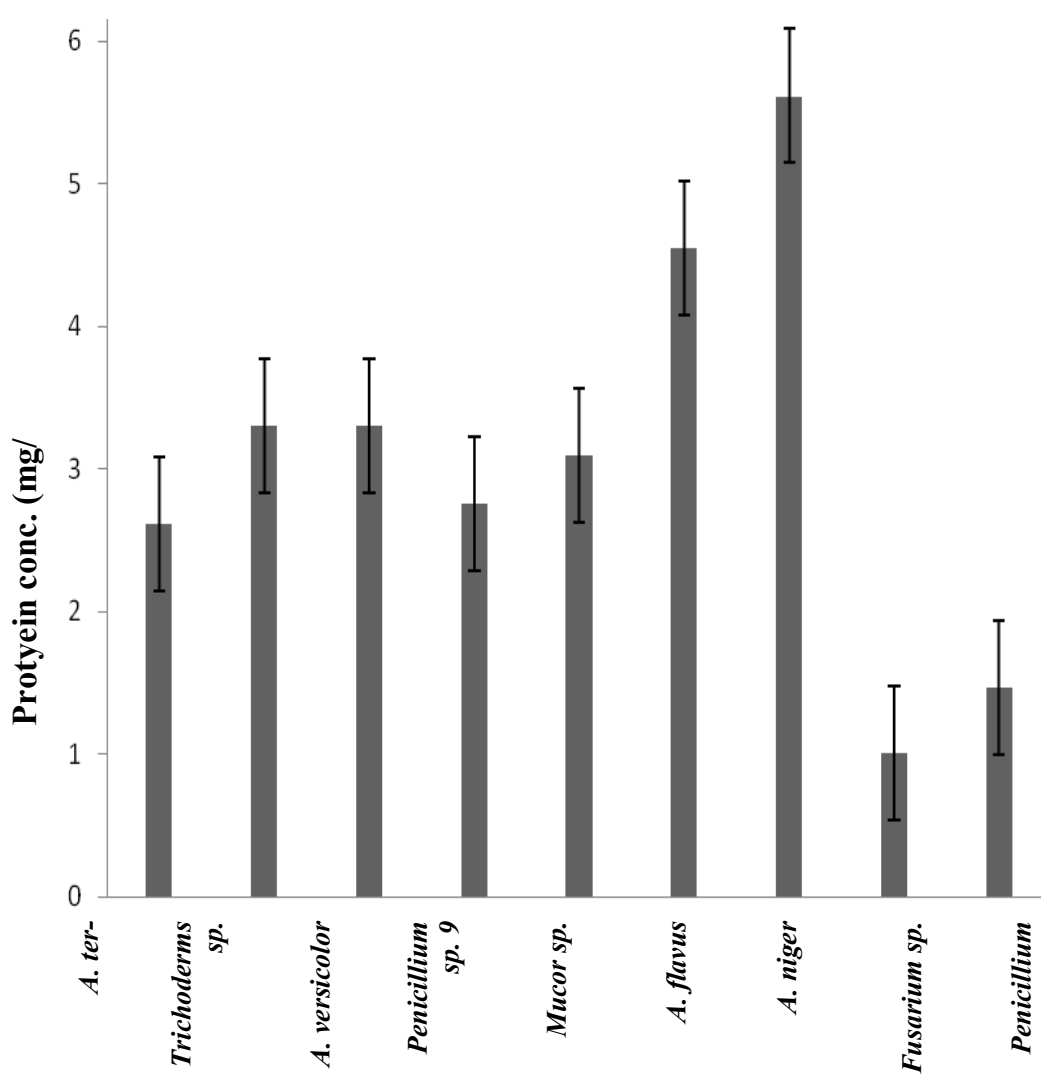

Cellulolytic isolates

Fig. 3: Mean protein conc. $(\mathrm{mg} / \mathrm{ml})$ of the cellulolytic isolates in CBB over 6 days period 
Burnett, H.L. and Hunter, B.B. (1972). Illustrated genera of imperfect fungi.3rd edition. Burgess publishing company, Minnespolis, Minnesota. p 88, 90, 126.

Ghose, T.K. (1987). Measurement of Cellulase Activities. Pure \& Appl. Chem. 59: 257268.

Guarro, J., Gene, J. and Stchigel, A.M. (1999). Developments in Fungal Taxonomy. Clinical Microbiology Reviews. 3:454-500.

Howard, R.L., Abotsi, E., Jansen van Rensburg, E.L. and Howard, S. (2003). Lignocellulose biotechnology: issues of bioconversion and enzyme production. Afr. J.Biotechnol. 2:602-619.

Immanuel, G., Bhagavath, C.M.A., Iyappa, R. P., Esakkiraj, P. and Palavesam, A. (2007) Production and Partial Purification of Cellulase by Aspergillus niger and A. fumigatus fermented in Coir waste and Sawdust. The Internet Journal of Microbiology. 3 (1):1-20.

Jeffries, T.W. (1987). Production and Application of cellulase laboratory procedures. USDA Forest products Laboratory, Madison, Winconsin. http://calvin.biotech. wisc.edu/jeffries/cellulases/mandels.html

Kader, A.J. and Omar, O. (1998). Isolation of Cellulolytic Fungi from Sayap-Kinabalu Park, Sabah. ARBEC article II p.1-6.

Khalid, M., Yang, W., Kishwar, N., Rajput, Z.I. and Arijo, A.G. (2006). Study of cellulolytic soil fungi and two nova species and new medium. Journal of Zhejiang University Science B. 6: 459-466.

Lynd, L.R., Weimer, P.J., Zyl, W.H. and Pretorius, I. S. (2002). Microbial cellulose utilization: fundamentals and biotechnology. MMBR. 66(3):506-577.

Maheshwari, R., Bharadwaj, G. and Bhat, M. (2000). Thermophilic Fungi: Their Physiology and Enzymes. Microbiology and Molecular Biology Reviews. 64(3):461488.
Malloch, D. (1997). An introductory guide to the study of moulds (fungi). Department of Botany, University of Toronto. http:// www.botany.utoronto.ca/ResearchLabs/ MallochLab/Malloch/Moulds $2^{\text {nd }}$ January, 2007.

Miyamoto, K. (1997). Production of fuel alcohol from cellulosic biomass: in renewable biological systems for alternative sustainable energy production. FAO Agricultural service Bulletin (128), Osaka University, Japan.

Olofsson, K., Bertilsson, M. and Liden, G. (2008). A short review on SSF-an interesting process option for ethanol production from lignocellulosic feedstocks. Biotechnology for Biofuels. 1(7):1-14.

Rajesh, A.R.R., Rajesh, E.M., Rajendran, R. and Jeyachandran, S. (2008). Production of bio-ethanol from cellulosic cotton waste through microbial extracellular enzymatic hydrolysis and fermentation. Electronic journal of environmental, agricultural and food chemistry. 7(6): 2984-2994.

Statistical assistance (2008). Assistat 7.5 beta. www.assistat.com, $3^{\text {rd }}$ January 2008.

Waravdakar, V., Goldblatt, P.J., Trump, B.F., Griffin, C.C. and Stowell, R. E. (1964). Effect of freezing and thawing on certain nuclear and mitochondrial enzymes of mouse liver. J. Histochem. Cytochem. 12 (7): 498-502.

Wang, N.S. (2008). Glucose assay by Dinitrosalicylic acid colourimetric method. Department of Chemical and Biomolecular, University of Maryland. www. glue.umd.edu/ nsw/ench485/lab4a.htm, $2^{\text {nd }}$ January, 2007.

www.doctorfungus.org, $3^{\text {rd }}$ January, 2008.

www.mycologyonline.adelaide.edu.au, $\quad 3^{\text {rd }}$ January 2008.

www.mycology.adelaide.edu.au/Mycoses/ Dimorphic_systemic, $3^{\text {rd }}$ January 2008. 